\title{
Kurs i depresjonsmestring - til nytte for hvem?
}

\author{
Kurs i depresjonsmestring (KID-kurs) er et populært kommunalt tilbud mot depresjon. Men effekten er uklar, \\ og man kan spørre seg for hvem kurset er utviklet.
}

KID-kursene er blitt et utbredt kommunalt tilbud mot depresjon, og Nasjonalt kompetansesenter for psykisk helsearbeid beskriver disse kursene som «veien til et friskere liv» (1). Dette virker veldig positivt, men hvor effektive er egentlig disse kursene?

Kursene er inspirert av Lewinsohns Coping with depression fra 1984 (2), som er basert på kognitive og atferdsmessige prinsipper. I innledningen beskriver Lewinsohn at hele $80 \%$ av kursdeltagerne ikke lenger var deprimert etter å ha fullført kurset.

Et større europeisk prosjekt ble igangsatt for å teste effekten mer systematisk (3).

Kursene ble sammenlignet med seks timers problemløsning. Problemløsningsintervensjonen ble faktisk beskrevet som mer akseptabel for deltagerne enn kursene. Det var et fåtall som opplevde klinisk signifikant bedring, og det var mange som droppet ut av kursene $(56 \%)$. Konklusjonen i rapporten var imidlertid at begge disse intervensjonene kunne anbefales for behandling av depresjon. I metaanalyser støtter man også opp under denne konklusjonen og hevder at slike kurs har en effekt som er sammenlignbar med øvrig psykoterapi (4).

\section{Hva er meningsfull endring?}

Det at en metode er dokumentert betyr ikke det samme som at den gir veldig gode resultater. I en norsk randomisert kontrollert studie så man på effektiviteten til KID-kurs (5), der deltagerne kunne gå i behandling andre steder samtidig som studien pågikk. Kontrollgruppen mottok ingen form for intervensjon. I denne studien hevdet man at $69 \%$ av kursdeltagerne ble bedre fra sine depressive symptomer sammenlignet med $37 \%$ i kontrollgruppen (som altså bare ventet). Man konkluderte med at kurset var effektivt mot depressive plager, og at det egnet seg til bruk i primærhelsetjeneste og psykisk helsetjeneste.

Hvis man ser studien litt nærmere etter i sømmene, kan man stille spørsmål ved hvor effektive kursene faktisk var. Kravet for bedring ble satt til seks poengs bedring på Beck Depression Inventory (BDI), men et slikt krav sier lite om meningsfull endring for deltagerne. Hva ligger bak tallene? Det var 81 personer som deltok på kursene, og $85 \%$ som gjennomførte. Totalt 46 av de 81 tilfredsstilte bedringskravet, tilsvarende $57 \%$. Gjennomsnittsskåren på BDI-skalaen gikk fra 21,8 (SD = 7,9) før oppstart til 14,1 $(\mathrm{SD}=9,3)$ ved avslutning. Dette kan tyde på at majoriteten av deltagerne gikk fra en mild og moderat depresjon ved oppstart til en mild depresjon ved avslutning.

Studien om disse norske KID-kursene ble publisert på nytt i et internasjonalt tidsskrift (6). Denne gangen ble det rapportert hvor mange som hadde en BDI-skår på under ti poeng etter fullført kurs. Kun $28 \%$ hadde dette. I likhet med kravet om bedring på seks poeng, blir også kravet om å komme

\section{«Det at en metode er dokumentert betyr ikke det samme som at den gir veldig gode resultater»}

under ti poeng noe meningsløst når det står alene. For at man skal ha en god effekt av behandling må man ha en tydelig endring i depresjonssymptomer samtidig som man må ende opp med et symptomtrykk klassifisert som innenfor normalen. Et bedre utfallsmål hadde vært en kombinasjon av to slike krav.

Bildet som tegnes av slike kurs blir med denne gjennomgangen altså noe gråere enn at dette er «veien til et friskere liv» og noe som bør implementeres i storstilt omfang. Fra Lewinsohns rapportering om $80 \%$ suksessrate er tallene nå nede til en anslått suksessrate på rundt $20 \%$. Det faktum at $24 \%$ av kursdeltagerne mottok annen behandling samtidig gjør at man blir usikker på hvor effektive kursene faktisk var. Det kan imidlertid være mange og sammensatte grunner til at effekten ikke var høyere.

\section{Er det enkle alltid det beste?}

Rasjonalen for utviklingen av KID-kurs i det europeiske prosjektet var å «identifisere to enkle, reproduserbare intervensjoner som kunne tilbys i samfunnet uten kompleks infrastruktur i helsetilbudet eller dyre helsearbeidere» $(3, \mathrm{~s} .1)$.

Intervensjonen skal altså være enkel å lære, billig og den skal leveres ut til de store massene. Kurslederne får et fem dagers teorikurs på til sammen 36 timer, men hva slags effekt har denne opplæringen? Kanskje enkle og billige løsninger ikke er løsningen på komplekse livssituasjoner og psykiske lidelser? Det kan tenkes at visse menneskelige utfordringer og lidelser er såpass komplekse at man trenger tettere oppfølging av en ekspert.

Det blir sagt at alle deltagere på slike kurs fyller ut BDI-skjemaet underveis (1). Gitt det store omfanget av slike kurs burde dette være en gullgruve for å drive kvalitetssikring av praksis og for å etablere et kvalitetsregister. Det hadde vært meget spennende og nyttig å se hvordan tallene er med så store utvalg.

\section{Stian Solem}

stian.solem@svt.ntnu.no

Stian Solem (f. 1978) er psykologspesialist og førsteamanuensis ved Psykologisk Institutt, NTNU, Norges teknisk-naturvitenskapelige universitet, Trondheim.

Forfatter har fylt ut ICMJE-skjemaet og oppgir ingen interessekonflikter.

\section{Litteratur}

1. NAPHA. KID-kurs veien til et friskere liv. www.napha.no/content/14879/KID-kurs-veien-tilet-friskere-liv (15.3.2016).

2. Lewinsohn PM, Antonuccio DO, Breckenridge JS et al. The «coping with depression» course. Eugene, OR: Castalia, 1984.

3. Dowrick C, Dunn G, Ayuso-Mateos JL et al. Problem solving treatment and group psychoeducation for depression: multicentre randomised controlled trial. BMJ 2000; 321: 1450-4.

4. Cuijpers P, Muñoz RF, Clarke GN et al. Psychoeducational treatment and prevention of depression: the «Coping with Depression» course thirty years later. Clin Psychol Rev 2009; 29: 449-58.

5. Dalgard OS. Kurs i mestring av depresjon-en ran domisert, kontrollert studie. Tidsskr Nor Lægeforen 2004; 124: 3043-6.

6. Dalgard OS. A randomized controlled trial of a psychoeducational group program for unipolar depression in adults in Norway (NCT00319540). Clin Pract Epidemol Ment Health 2006; 2: 15.

Mottatt 20.6. 2016, første revisjon innsendt 27.6. 2016, godkjent 28.6. 2016. Redaktør: Ketil Slagstad.

Publisert først på nett. 